\title{
The Challenges Experienced by Professional Teachers in Teaching and Learning on Online Platform
}

\author{
Fidel $^{1 *}$ and Sitti Fatimah ${ }^{2}$ \\ ${ }^{12}$ English Department, FBS Universitas Negeri Padang, Padang, Sumatera Barat 25131, Indonesia \\ *Corresponding author. Email: fidelramone@gmail.com
}

\begin{abstract}
Indonesian professional teachers are demanded to master four basic competencies: spiritual, social, pedagogical, and professional competencies. Professional competency requires teachers to be able to apply information and communication technology (ICT) in both online and offline learning mode. Online learning has been increasingly conducted as the impact of the Covid-19 pandemic. In some areas, the pandemic has forced teachers to use full online learning and to learn new online learning platforms that too many teachers are difficult to do. Further investigation is needed to know how the teachers use the platforms. The observed situation shows that the teachers are still lack understanding in using some online platform. They also find some difficulties in integrating ICT in their teaching and learning. This article discusses teachers' challenges in using ICT, particularly online learning platforms.
\end{abstract}

Keywords: learning challenges, professional teachers, online platform

\section{INTRODUCTION}

Indonesian professional teachers are demanded to master four basic competencies: spiritual, social, pedagogical, and professional competencies. According to the Ministry of Education and Culture, it states that professional teachers are teachers who have 4 competencies in carrying out their profession, which consists of stating that teachers have pedagogical, personal, social, and professional competencies. This competence does not directly reflect the ability of teachers to hold teaching and learning activities. Professional competency requires teachers to be able to apply information and communication technology (ICT) in both online and offline learning mode. Teaching today has been implemented using many ways, using conventional classroom meetings, virtual learning, group learning, etc. Teachers are required to be able to apply various sources and media in any condition in conducting the teaching process whether in or out of the classroom, especially in using technology.

Online learning has been increasingly conducted as the impact of the Covid-19 pandemic. Along with the technology use, the certified teachers should be able to operate any technology-related on the education process, whether it is using the media, laptop, finding any source on the internet, having a virtual classroom, etc. The certified teachers are the teachers who got trained through the teacher training provided by the government. As in contrast to the findings, Haryanto et al., Kusumawardhani, and Ree et al. question in their papers about how the certified teacher should improve their skills and competency towards students and the teachers themselves. It means that what the teachers should do is improving themselves with any provided resources given [1]-[3].

In worldwide context, some countries (China, Georgia, India, Nepal, Nigeria, Philippines, Uzbekistan) Basilaia \& Kvavadze; Dawadi \& Simkhada; Khusanov et al.; Onyema; Toquero ; Zhu \& Liu, listed that pandemic give some impacts on development of open educational platforms; research and evaluate current models of online teaching and learning; develop staff-teachers' capacity for online teaching, and professional staff capacity; encourage cooperation between universities, international organizations, private sector, civil society, and other stakeholders; helps teachers master the students' process learning data to effectively improve teaching; schools actively develop school-based online teaching re-sources; educational big data; effectiveness of using online platforms; establish strict online learning and teaching management system; variety of online teaching modes; more mature home-school management mechanism; establishes a classroom teaching model; emergency remote teaching; coronavirus school closures; challenges and possible strategies to respond to COVID19 impact on the school education [4]-[9] .

Into local context towards Indonesia, some researches in their papers Wahyuningsih; Abidin et al., Eko et al.; Komang \& Astini; Lestiyanawati \& Widyantoro; Pajarianto et al.; and Yulia stated that in Indonesia situation of Covid-19 Pandemic resulted in: More changes in adapting towards pandemic situation such as learning tool; learning environment, application, 
the effectiveness of online learning, and reshaping the education. Better adaptation on teaching strategies, teaching problem, and using e-learning on teaching. Variations on teachers' activities in the online class. More parents and teachers support unpredictable situation changes on students; Project-based learning; Preventing pandemic spread; In short, based on the conducted researches, the Covid-19 give significant impact towards the teacher, education system, students, time management, technology, and keeping the health safety protocol itself. It should be known that Covid had limited resources, readiness, teacher beliefs on certified teachers, and the impact on online learning [10]-[16].

Further inspections are needed to know and what are the challenges faced and the prospect of certified teachers and online learning. in the research, it is taken on the concept of the timeframe of online learning and disadvantages-advantages in online learning [16]. Another research states that taken as the way they conducted data collection towards teachers about teaching feedback and the problems [12]. In another writing, it has been taken about the variety's application used and the unsupportive during the situation [13]. It is noted on the points of the teacher as supportive aspects during a pandemic situation in this research [11]. And it has been pointed out as the way in collecting data and the most common application used in online class [10].

The differences of this research are focusing on the teacher professionality and pedagogical challenges in using the online platforms as the situation in Indonesia today has shifted more on using the online platforms in the teaching and learning process. As the teachers here are certified teachers, they have already trained to be professional in using kind of technology and using their pedagogical in planning the lessons. This research will reveal how the teacher's challenges on the online platform, especially on the junior high school level. It can give more description of anything related to technology use as well as the teaching and learning processes.

\section{METHODOLOGY}

The research was qualitative, which means that the research was intended to get more explanation, interpretation, comprehensive, and non-numerical data to get the final generalization of research interest based on teacher's professionality. The participant in this research was the English Teacher for 9th grade in SMPN in Ampek Angkek. The data is about the teacher's view based on the interview-based, as the interview was intended to know the teacher's view in using the online platform [17]. Due to the Covid-19 situation, the interview was being recorded by phone. Three teachers who already get certification training on 9th graders had the interviews.
The research was conducted while in classroom activity and outside of the classroom. The participants are three certified English teachers on the 9th Grade level in Ampek Angkek, Baso Sub-District, Agam District, West Sumatera province. The data were taken from the teachers while by asking some semi-structured question related to their process in doing the online classroom in COVID-19 situation, it may reveal what the teachers' opinion related their professional competence in using the online platform

Interview about virtual learning on the online platform was taken about the teacher identity related to the school name, teacher name, the duration of duty [17]. Another point is about the teacher's background of education which is about the level, certification status, duration of being a civil servant teacher, the reason for being an English teacher, and the most memorable in learning and teaching English.

The second big point of this interview was finding of the teacher's view in using the online platform, those are related the impact, types of the online platform being used, the advantages of using the online platform, the challenges of using the online platform, possible solution the challenges by the teachers, what kind of material used on online learning, and using the online platform intensity.

In analyzing the data, the interview data were analyzed by reading all the interviews to get the generalization, meaning, and descriptive meaning [18]

\section{RESULTS}

A teacher (ED) stated that her school has been shifted into three types of situations of learning. The first one was about full online learning. On the second one, once a week the student would come to school just only for submitting the tasks. On the last type, the school had been started to 2 days for a limited meeting on each classroom level. In her classroom for (9th graders), it was having an offline meeting on Monday and Tuesday, and the rest of the days were online. ED has bee teaching for 30 years and has been certified since 2011. Her last education is S-1 (Bachelor Degree in English Language Education). Her impression of being a teacher was because of her English teachers when ED was in Junior and Senior high School.

ED saw that the online platform in learning motivated the teachers in using and learning the application, such as using Google Form. Yet, due to her age factor, it is needed for her to get more assistance for using the online platform and followed by boredom and eye-retention. ED also added that due to the high intensity of using mobile phones by the learners, it is affecting their attention and motivation, not only in English subjects. 
The students also intended to do cheating among them especially on weekly evaluation tests.

ED restated that had used Google classroom, google meet, zoom, and voice chat using WhatsApp. She felt sorry that many of the students are unable to buy additional data packages due to limited application support, then twice a week offline meeting was needed.

The challenges it took ED's patience to become literate on technology, boredom, and eye strain. Then the students are less motivated and participated. Moreover, students are less sympathetic to their lesson, especially on their scores. Besides, the parents were surprisingly less coordinated and supportive of what condition the student faced.

Talking about the solution, ED proposed that the twice a week offline meeting will help the students to learn better, as it was known as trials until today. The teachers will have 40 minutes face to face meeting each to explain related task on the online platform, or any related discussion. The Online platform still have been being used until today for instruction matters, and the offline face-to-face meeting will be giving about the tasks or assignment.

Due to teaching on 9th graders, the material was directed about the National Examination, therefore more adaptation was needed by the teachers. ED added that on 7th graders used WhatsApp in the chatting room, on 8th graders used Zoom and google classroom, but had changed to zoom and WhatsApp. For another subject, the science teacher ever used video for teaching, but it was not continued. Focusing on the English subject, the preservice teacher also not attending the classroom, they also kept in touch with their mentor teacher and join the online platform classroom session. The pre-service teacher also helped the teacher in school to use the application in the online platform.

Moving into teacher professionalism on teaching using the online platform, ED had a positive attitude on it, it helped her in giving the material, managing the students, assessing the students' work, and giving enthusiasms to the teacher. The preparation for using the current curriculum is adapting the material based on the teacher's book or student's book, then upload it through WhatsApp or Google Form. ED confirmed that the books are being used are "When English Rings a Bell, Sing Global, and Bright."

ED also gave her opinion about this online platform it should be better for the younger teacher, even though she had been training in MGMP (Musyawarah Guru Mata Pelajaran or known as Teachers' forum), her age factor could not retain the information longer, but ED chose what the online platform at least she was able to operate it. Then, ED simplified her choices in using Google Form. Also, some teachers chose the best fit online platform for themselves, such as google meeting, google classroom, Zoom, or WhatsApp.

\section{DISCUSSION OF RESULTS}

Based on the interview, the teacher has already recognized her ability in using online platforms. It also means that her age factor affected her performance to choose various apps, yet every teacher chose on what their best on use. The school itself took three-time adaptation after the Covid-19 outbreaks on school. It makes the changes to the student less motivated and less attracted to their lesson, moreover the parents. It can be described that the online platform was still being used until today even with some limitations and changes in the school situation.

Moreover, it means that the teacher should be more aware related to the variousness of using technology in the online learning platforms, as it is one of the requirements of the professional teacher status. It should be noted that the parents' cooperativeness are also needed despite the pandemic situation. ED's in using the online platforms is positively welcome yet it takes more in training and adaptation if it is needed in sudden changes in the teaching situation.

\section{CONCLUSION}

Based on the finding of the interview of the challenges experienced by professional teachers in teaching and learning on the online platform, it is concluded that the teacher can use the online platform in their learning process, as well as on their pedagogy as it is implied that using online platform ease their managing students, giving material, and assessing the students. This study only took on the professional and pedagogical on the teacher's competence. To conclude, it is suggested to take more focus on the other teacher's competencies challenges while using the online platforms in teaching.

\section{REFERENCES}

[1] P. N. Kusumawardhani, "Does teacher certification program lead to better quality teachers? Evidence from Indonesia," Educ. Econ., vol. 25, no. 6, pp. 2017

doi: 10.1080/09645292.2017.1329405

[2] J. De Ree, S. Al-Samarrai, and S. Iskandar, "Teacher certification in Indonesia : a doubling of pay, or a way to improve learning?," no. 73264 October, pp. 1-6, 2012, [Online]. Available: http://documents.worldbank.org/curated/en/422651 468285048834/Teacher-certification-in-Indonesiaa-doubling-of-pay-or-a-way-to-improve-learning.

[3] A. Mukminin , E. Haryanto , R. Murboyono , M. Muazza and M. Ekatina, "Teacher certification 
policy in Indonesia: Evidence from certified English teachers at one public high school", Turkish Online Journal of Qualitative Inquiry, vol. 7, no. 3, pp. 224-244, Jul. 2016, doi:10.17569/tojqi.31703.

[4] G. Basilaia and D. Kvavadze, "Transition to Online Education in Schools during a SARS-CoV-2 Coronavirus (COVID-19) Pandemic in Georgia," Pedagog. Res., vol. 5, no. 4, 2020, doi: $10.29333 / \mathrm{pr} / 7937$.

[5] S. Dawadi and P. Simkhada, "Impact of COVID-19 on the Education Sector in Nepal - Challenges and Coping Strategies," Sage Submissions, vol. 3, no. May, p. 16, 2020, doi: 10.31124/advance.12344336.v1.

[6] K. Khusanov, G. Khusanova, and M. Khusanova, "Distance Education in Uzbekistan during the pandemic of Covid-19," Researchgate, June, 2020, doi: 10.13140/RG.2.2.29832.03847

[7] E. M. Onyema, "Impact of Coronavirus Pandemic on Education," IISTE (Journal of Education and Practice) vol. 11, no. 13, pp. 108-121, 2020, doi: 10.7176/JEP/11-13-12.

[8] C. M. D. Toquero, "Emergency remote teaching amid COVID-19: The turning point," Asian Journal of Distance Education, vol. 15, no. 1, pp. 185-188,

2005. http://www.asianjde.org/ojs/index.php/AsianJDE/a rticle/view/450

[9] X. Zhu and J. Liu, "Education in and After Covid19: Immediate Responses and Long-Term Visions," Postdigital Sci. Educ., 2020, doi: 10.1007/s42438020-00126-3.

[10] Effi Wahyuningsih, 'Kulwap: The EFL Learners' Perspectives on the Online English Course Conducted through WhatsApp Group Interactions," CLLIENT (Culture, Literature, Linguistics, English Teaching) vol. 2, no. 1,2020.pp.83-101. https://ojs.unsiq.ac.id/index.php/cllient/article/view $/ 1272$

[11] Z. Abidin, Rumansyah, and K. Arizona, "Pembelajaran Online Berbasis Proyek Salah Satu Solusi Kegiatan Belajar Mengajar Di Tengah Pandemi Covid-19," J. Ilm. Profesi Pendidik., vol. 5, no. 1, pp. 64-70, 2020, doi: https://doi.org/10.29303/JIPP.V5I1.111.

[12] A. Eko, P. Atmojo, A. Nugroho, and C. Author, "EFL Classes Must Go Online! Teaching Activities and Challenges during COVID-19 Pandemic in Indonesia," Register Journal vol. 13, no. 1, pp. 4976 , 2020.

DOI: https://doi.org/10.18326/rgt.v13i1.49-76

[13] N. Komang and S. Astini, "Tantangan Dan Peluang Pemanfaatan Teknologi Informasi Dalam Pembelajaran Online Masa Covid-19," Cetta;
Jurnal Ilmu Pendidikan, vol. 3, no. 2, pp. 241-255, 2020. https://doi.org/10.37329/cetta.v3i2.452

[14] R. Lestiyanawati and A. Widyantoro, "Strategies and Problems Faced by Indonesian Teachers in Conducting E- Learning System During COVID-19 Outbreak," CLLIENT (Culture, Literature, Linguistics, English Teaching), vol. 2, no. 1, pp. 7182 ,

2020.https://ojs.unsiq.ac.id/index.php/cllient/article /view/1271

[15] H. Pajarianto, A. Kadir, N. Galugu, P. Sari, and S. Februanti, "Study from Home in the Middle of the COVID-19 Pandemic: Analysis of Religiosity, Teacher, and Parents Support Against Academic Stress," J. Talent Dev. Excell., vol. 12, no. 2, pp. 1791-1807, 2020.

[16] H. Yulia, "Online Learning to Prevent the Spread of Pandemic Corona Virus in Indonesia," ETERNAL (English Teach. Journal), vol. 11, no. 1, pp. 48-56, 2020, doi: 10.26877/eternal.v11i1.6068.

[17] C. Ismaniati and Darmawansah, "how virtual learning works for indonesian efl teachers in teaching spanish students: a case study in wonder english academy spain," no. 2, pp. 23-37, 2019 [Online]. Available: http://repositorio.unan.edu.ni/2986/1/5624.pdf.

[18] J. K. Author, "Transcript and Analysis," in The Research Interview, 1th edition. New York City, USA: Palgarave Macmillan, 2016, ch. 8, pp. 210. 